\title{
PENGARUH HARGA DAN PROMOSI TERHADAP IMPULSE BUYING PADA PRODUK ONLINE MENURUT EKONOMI SYARIAH
}

\section{THE EFFECT OF PRICE AND PROMOTION ON IMPULSE BUYING ONLINE PRODUCTS ACCORDING TO THE SHARIA ECONOMY}

\author{
Mufti Hasan Alfani \\ Universitas Islam Riau \\ muftihasanalfani@fis.uir.ac.id
}

\begin{abstract}
ABTRACT
Advances in internet technology currently make online shopping systems become instant and very popular. This study aims to determine the analysis of the Effect of Prices and Promotions on Impulse Buying in Online Products According to Islamic Economics. Where the results of the pre-survey to students of the Faculty of Islam about Online products on the influence of prices and promotions on impulsive purchases. The sampling technique in this study used a purposive sampling technique by taking a sample of 100 respondents. This research uses a quantitative approach with the method of data analysis of Multiple Linear Regression with the help of the SPSS Program Application Version 21.0 for Windows. The results of this study indicate that there is an effect of Price and Promotion on the performance of Impulse Buying on online products. As well as the effect of Price and Promotion on Impulse Buying in the Sharia Economy perspective on the influence of consumer behavior on purchasing decisions via mobile phones they apply concepts that are in accordance with the teachings of Islam that is not beyond the limits of reasonableness, and positively. Because the AlQur'an forbids excessive spending on wealth solely following the passions, while on the other hand also condemns the act of distancing yourself from the pleasure of enjoying things that are good and lawful in life.
\end{abstract}

Keywords: Price, Promotion, Impulse Buying, Online Products, Sharia Economy.

\begin{abstract}
ABSTRAK
Kemajuan teknologi internet saat ini membuat sistem belanja online pun menjadi hal yang instan dan sangat diminati. Penelitian ini bertujuan untuk mengetahui analisis Pengaruh Harga Dan Promosi Terhadap Impulse Buying Pada Produk Online Menurut Ekonomi Syariah. Dimana hasil pra survey kepada mahasiswa Fakultas Agama Islam tentang produk Online atas pengaruh harga dan promosi terhadap pembelian secara impulsif. Teknik pengambilan sampel dalam penelitian ini menggunakan teknik purposive sampling dengan mengambil sampel sebanyak 100 responden. Penelitian ini menggunakan pendekatan kuantitatif dengan metode analisis data Regresi Linier Berganda dengan bantuan Aplikasi Program SPSS Versi 21.0 for Windows. Hasil penilitian ini menunjukkan bahwa adanya pengaruh Harga dan Promosi terhadap kinerja Impulse Buying pada produk Online. Serta pengaruh Harga dan Promosi terhadap Impulse Buying dalam perpektif Ekonomi Syariah dalam pengaruh perilaku konsumen terhadap keputusan pembelian melalui telepon genggam mereka menerapkan konsep yang sesuai dengan ajaran agama Islam yaitu tidak melampaui batas kewajaran, dan secara positif. Karena Al-Qur'an melarang membelanjakan harta secara berlebih-
\end{abstract}


lebihan semata-mata menuruti hawa nafsu,sementara disisi lain juga mengutuk perbuatan menjauhkan diri darikesenangan menikmati benda-benda yang baik dan halal dalam kehidupan.

Kata Kunci :Harga, Promosi, Impulse Buying, Produk Online, Ekonomi Syariah.

\section{PENDAHULUAN}

Perkembangan teknologi informasi yang meningkat pesat pada tahun-tahun terakhir juga telah membawa beberapa dampak perubahan pada beberapa aspek kehidupan, seperti halnya kini berbelanja tidak harus bertatap muka, dengan adanya internet maka belanja online pun menjadi hal yang instan. Manusia tidak perlu lagi pergi ke pasar atau ke toko untuk mencari barang yang diinginkannya. Dengan bermodalkan koneksi internet, memesan barang, melakukan pembayaran hingga barang yang dipesan sampai didepan rumah dapat dilakukan dengan mudah (Hamzah et al., 2018).

Pesatnya jaringan internet juga secara tidak langsung membawa fenomena baru atau gaya hidup baru di kalangan masyarakat yang suka memanfaatkan fasilitas internet, salah satunya adalah belanja online. Ada banyak produk online yang ditawarkan seperti produk fashion, elektronik, kosmetik, dan lain-lain yang ditawarkan di internet dan menawarkan kemudahan dalam cara berbelanja dan pembayaran.

Saat ini, sangat potensial untuk melakukan pembelian impulsif secara online. Ditemukan bahwa terdapat hubungan antara perilaku pembelian online secara impulsif dengan kemampuan sosial ekonomi pembeli potensial. Media internet juga merupakan media yang lebih sering terjadinya impulsive (Miranda, 2016).

Dalam Islam, konsumsi tidak dapat dipisahkan dari peranan keimanan. Peranan keimanan menjadi tolak ukur penting karena keimanan memberikan cara pandang dunia yang cenderung mempengaruhi kepribadian manusia. Keimanan sangat mempengaruhi kuantitas dan kualitas konsumsi baik dalam bentuk kepuasan material maupun spiritual. Konsumsi harus memerhatikan tingkat maslahah, yaitu pada diri sendiri, keluarga dan kepentingan maslahah orang banyak bahkan harus akhirat oriented. Ajaran Islam mengajarkan untuk hidup sederhana, dan menjauhi sikap boros (memubadzirkan harta) dan bermewahmewahan.

Mahasiswa Fakultas Agama Islam Universitas Islam merupakan salah satu kelompok yang sering melakukan pembelian suatu produk secara online. Hal ini dikarenakan banyaknya kemudahan yang diberikan. Akan tetapi, mereka juga sering membeli tanpa melakukan perencanaan terlebih dahulu. Hal ini dibuktikan dengan wawancara pra survei dari salah satu mahasiswa Fakultas Agama Islam Universitas Islam Riau yang menyebutkan bahwa ia pernah membeli suatu produk online secara tiba-tiba atau tidak direncanakan sebelumnya dengan alasan harga yang ditawarkan cukup murah dan juga karena adanya promosi yang menarik. Ini mengindikasikan bahwa adanya pengaruh harga dan promosi terhadap impulse buying pada mahasiswa Fakultas Agama Islam Universitas Islam Riau.

Pembelian impulsif (impulse purchase), adalah tindakan membeli yang sebelumnya tidak diakui secara sadar sebagai hasil dari pertimbangan, 
atau niat membeli yang terbentuk sebelum memasuki toko (Rahmasari, 2016). Atau bisa juga dikatakan suatu desakan hati yang tiba - tiba dengan penuh kekuatan, bertahan \& tidak direncanakan untuk membeli sesuatu secara langsung, tanpa banyak memperhatikan akibatnya. Konsumen yang melakukan impulse buying tidak berpikir untuk membeli produk atau merek tertentu. Mereka langsung melakukan pembelian karena ketertarikan pada merek atau produk saat itu juga. Konsumen cenderung untuk membeli secara spontan, reflek, tiba-tiba, dan otomatis. Impulse buying dapat disebabkan oleh beberapa hal, seperti display yang menarik ataupun karena harga diskon menurut. Padahal seharusnya menjadi konsumen harus memperhatikan proses pengambilan membeli yang tahapannya dimulai dari pengenalan masalah yaitu berupa desakan yang membangkitkan tindakan untuk memenuhi dan memuaskan kebutuhannya, selanjutnya tahap mencari informasi tentang produk yang dibutuhkan yang dilanjutkan tahap evaluasi alternatif yang berupa penyeleksian selanjutnya tahap pembelian dan diakhiri dengan perilaku sesudah pembelian dimana membeli lagi.

Pada dasarnya faktor-faktor yang dapat mempengaruhi perilaku konsumen adalah faktor situasional, psikologis, marketing mix, dan sosial budaya (Fadliyah, 2015). Faktor situasional meliputi lingkungan sosial, lingkungan fisik, dampak sementara, dan keadaan sebelumnya. Faktor psikologis meliputi motivasi, persepsi pembelajaran, sikap dan psikologiapik. Faktor marketing mix meliputi produk, harga, promosi, dan distribusi, sedangkan faktor sosial dan budaya meliputi kelompok referensi, keluarga, kelas, sosial dan budaya.
Dalam Islam, konsumsi tidak dapat dipisahkan dari peranan keimanan. Peranan keimanan menjadi tolak ukur penting karena keimanan memberikan cara pandang dunia yang cenderung mempengaruhi kepribadian manusia. Keimanan sangat mempengaruhi kuantitas dan kualitas konsumsi baik dalam bentuk kepuasan material maupun spiritual (Sholihah et al., 2017).

Dalam arti yang paling sempit, harga (price) adalah jumlah uang yang dibebankan atas suatu produk atau jasa. Lebih luas lagi, harga adalah jumlah dari seluruh nilai yang ditukar konsumen atas manfaat-manfaat memiliki atau menggunakan produk atau jasa tersebut Harga merupakan suatu alat pemasaran yang dipergunakan oleh suatu organisasi (marketing objectives) (Purwati et al., 2017). Harga merupakan alat yang sangat penting yang merupakan faktor yang mempengaruhi keputusan pembeli di dalam sektor publik.

Faktor utama dalam peningkatan harga adalah inflasi biaya. Meningkatkan biaya memeras margin laba dan membuat perusahaan memindahkan peningkatan biaya itu kepada pelanggan. Faktor lain yang menyebabkan peningkatan harga adalah kelebihan permintaan. Ketika perusahaan tidak dapat menyediakan semua yang dibutuhkan pelanggannya, perusahaan dapat menaikkan harganya, membatasi produk terhadap pelanggan, atau keduanya.

Dalam konsep ekonomi Islam harga ditentukan oleh keseimbangan permintaan dan penawaran. Keseimbangan ini tidak terjadi bila antara penjual dan pembeli tidak bersikap saling merelakan. Kerelaan ini ditentukan oleh penjual dan pembeli dalam mempertahankan kepentingannya 
atas barang tersebut (Pertaminawati, 2016).

Dalam ekonomi Islam siapa pun boleh berbisnis. Namun demikian, dia tidak boleh melakukan ikhtikar, yaitu mengambil keuntungan di atas keuntungan normal dengan menjual lebih sedikit barang untuk harga yang lebih tinggi. Setiap keputusan ekonomi seorang manusia tidak terlepas dari nilai-nilai moral dan agama karena setiap kegiatan senantiasa dihubungkan kepada syariat. Al-Qur'an menyebut ekonomi dengan istilah iqtishad (penghematan, ekonomi), yang secara literal berarti 'pertengahan' atau 'moderat'. Seorang muslim diminta untuk mengambil sebuah sikap moderat dalam memperoleh dan menggunakan sumber daya. Dia tidak boleh israf (berlebih-lebihan), tetapi juga dilarang pelit (bukh) (Aprillia, 2017).

Ta'sir (penetapan harga) merupakan salah satu praktek yang tidak dibolehkan syariat Islam. Pemerintah ataupun yang memiliki kekuasaan ekonomi tidak memiliki hak dan kekuasaan untuk menentukan harga tetap sebuah komoditas, kecuali pemerintah telah menyediakan untuk para pedagang jumlah yang cukup untuk dijual dengan menggunakan harga yang telah disepakati bersama.

Penelitian oleh Dalihade (2017)

dan Wahyudi (2017) menunjukkan bahwa harga merupakan faktor yang berpengaruh signifikan terhadap impulse buying.

Promosi berasal dari kata promote dalam bahasa inggris yang artinya mengembangkan atau meningkatkan. Promotion (promotion) adalah mengomunikasikan informasi antara penjual dan pembeli potensial atau orang lain dalam saluoran untuk memengaruhi sikap dan perilaku. Promosi juga merupakan kegiatan marketing mix yang terakhir setelah produk, harga, dan tempat, serta inilah yang paling sering diidentikkan sebagai aktivitas pemasaran dalam arti sempit (Sunjoto, 2017).

Promosi berdasarkan prinsip syariah adalah promosi yang jujur, transparan, dan menjelaskan apa adanya. Di dalamnya tidak terdapat unsur-unsur kebohongan dan penipuan baik dari segi kuantitas maupun kualitas. Pada satu sisi harus menyampaikan apa adanya walaupun mungkin tidak akan berdampak luar biasa bagi penjualan karena tidak dibesar-besarkan, namun berkah. Tapi pada sisi lain tidak dibenarkan menyampaikan informasi yang mengandung kebohongan, apalagi penipuan.

Promosi dalam Islam juga dapat diambil contoh dari sistem promosi yang dilakukan oleh Rasulullah SAW. Promosi yang dilakukan Rasulullah SAW lebih menekankan pada hubungan dengan pelanggan (Sunjoto, 2017).

Penelitian yang pernah dilakukan oleh Fadliyah (2015), Putri (2017) dan Alfaiz (2018) memperoleh hasil dimana promosi yang dilakukan oleh suatu produk atau perusahaan dapat memberikan pengaruh kepada terjadinya impulse buying konsumen.

Berdasarkan latar belakang fenomena dan beberapa penelitianpenelitian relevan terkait impulse buying, maka dari itu penelitian ini mencoba memperbarui konsep impulse buying dan faktor-faktor yang mempengaruhinya dengan melihat kepada perspektif agama khususnya agama islam. Karena perkembanganperkembangan teknologi saat itu yang menyebabkan segala sesuatunya serba instan memberikan kemudahankemudahan bagi setiap masyarakat, namun kemudahan tersebut tidak boleh terlepas dari etika-etika keislaman. 


\section{METODE PENELITIAN}

Penelitian ini dilaksanakan di Universitas Islam Riau yang beralamat di Jl. Kaharuddin Nasution, Perhentian Marpoyan, Simpang Tiga, Pekanbaru Riau. Adapun objek penelitiannya adalah Mahasiswa Fakultas Agama Islam Universitas Islam Riau. Teknik pengambilan sampel peneliti menggunakan teknik purposive sampling yaitu teknik sampling yang digunakan oleh peneliti jika peneliti mempunyai pertimbanganpertimbangan tertentu dalam mengambil sampelnya.

Sampel yang akan diambil merupakan mahasiswa Fakultas Agama Islam khususnya jurusan Ekonomi Syariah yang berjumlah 100 responden menggunakan rumus slovin. Pertimbangan tersebut didasarkan pada kepentingan atau tujuan penelitian. Pertimbangan yang digunakan dalam pengambilan sampel adalah mahasiswa yang masih tercatat sebagai mahasiswa aktif dan pernah bertransaksi serta sesuai bidang dalam kajian penelitian di Fakultas Agama Islam Universitas Islam Riau.

Teknik pengumpulan data yang dilakukan dengan cara memberikan seperangkat daftar pertanyaan atau pernyataan tertulis untuk memperoleh keterangan dari sejumlah responden. Penelitian ini menggunakan bentuk Angket langsung tertutup yang dirancang sedemikian rupa untuk memperoleh data tentang keadaan yang dialami responden, kemudian semua alternatif jawaban telah tertera dalam angket sehingga responden tinggal memilih salah satu jawaban yang sesuai. Instrumen yang diberikan kepada responden dengan menggunakan teknik skala likert 5 poin untuk mengukur variabel penelitian.
Adapun Metode Analisis Data yang digunakan dalam penelitian ini adalah pendekatan kuantitatif dengan metode analisis data Regresi Linier Berganda dengan bantuan Aplikasi Program SPSS Versi 21.0 for Windows.

\section{HASIL DAN PEMBAHASAN Uji Validitas}

Uji Validitas adalah sebuah alat yang digunakan untuk mengukur sah atau tidaknya kuesioner. Suatu kuesioner dikatakan valid jika pertanyaan pada kuesioner tersebut mampu mengungkapkan sesuatu yang akan diukur oleh kuesioner tersebut. Menurut Sekaran validitas menguji seberapa baik suatu instrument dibuat mengukur konsep tertentu yang ingin diukur atau dengan kata lain untuk menunjukkan tingkat kehandalan suatu instrumen. Suatu instrumen yang valid mempunyai validitas tinggi. Instrumen dikatakan valid apabila mampu mengukur apa yang diinginkan, mampu mengungkapkan data dari variabel yang diteliti secara tepat. Tinggi rendahnya validitas instrumen menunjukkan sejauh mana data yang terkumpul tidak menyimpang dari gambaran tentang validitas yang dimaksud.

Untuk mengetahui konsistensi atau akurasi data yang dikumpulkan, dilakukan uji validitas dengan menggunakan SPSS. Perhitungan validitas instrumen dilakukan dengan cara melihat nilai Corrected Item-Total Correlation yang merupakan $r$ hitung dari hasil perhitungan validitas instrument penelitian, $r$ hitung kemudian dibandingkan dengan $r$ tabel yang merupakan sebuah standard atau acuan. Suatu instrumen dikatakan valid bila $r$ hitung lebih besar dari pada $r$ tabel ( $r$ hitung $>t$ tabel). Hasil uji validitas pada indikator-indikator penelitian ini terdapat pada tabel berikut ini. 
Tabel 1 Hasil Uji Validitas X1

\begin{tabular}{lccc}
\hline \multicolumn{1}{c}{ Pernyataan } & r-hitung & r-tabel & Kesimpulan \\
\hline Pernyataan 1 & 0.813 & 0.215 & Valid \\
\hline Pernyataan 2 & 0.702 & 0.215 & Valid \\
\hline Pernyataan 3 & & 0.215 & Valid \\
\hline Pernyataan 4 & 0.658 & 0.215 & Valid \\
\hline Pernyataan 5 & 0.423 & 0.215 & Valid \\
\hline Pernyataan 6 & 0.775 & 0.215 & Valid \\
\hline Pernyataan 7 & 0.813 & 0.215 & Valid \\
\hline Pernyataan 8 & 0.702 & 0.215 & Valid \\
\hline Pernyataan 9 & 0.603 & 0.215 & Valid \\
\hline Pernyataan 10 & 0.658 & 0.215 & Valid \\
\hline
\end{tabular}

Sumber: Data Diolah (2019)

Tabel 2 Hasil Uji Validitas $\mathbf{X}_{2}$

\begin{tabular}{lccc}
\hline \multicolumn{1}{c}{ Pernyataan } & r-hitung & r-tabel & Kesimpulan \\
\hline Pernyataan 1 & 0.423 & 0.215 & Valid \\
\hline Pernyataan 2 & 0.775 & 0.215 & Valid \\
\hline Pernyataan 3 & 0.813 & 0.215 & Valid \\
\hline Pernyataan 4 & 0.702 & 0.215 & Valid \\
\hline Pernyataan 5 & 0.603 & 0.215 & Valid \\
\hline Pernyataan 6 & 0.658 & 0.215 & Valid \\
\hline Pernyataan 7 & 0.723 & 0.215 & Valid \\
\hline Pernyataan 8 & 0.434 & 0.215 & Valid \\
\hline Pernyataan 9 & 0.778 & 0.215 & Valid \\
\hline Pernyataan 10 & 0.800 & 0.215 & Valid
\end{tabular}

Sumber: Data Diolah (2019)

Tabel 3 Hasil Uji Validitas Y

\begin{tabular}{lccc}
\hline \multicolumn{1}{c}{ Pernyataan } & r-hitung & r-tabel & Kesimpulan \\
\hline Pernyataan 1 & 0.702 & 0.215 & Valid \\
\hline Pernyataan 2 & 0.603 & 0.215 & Valid \\
\hline Pernyataan 3 & 0.658 & 0.215 & Valid \\
\hline Pernyataan 4 & 0.813 & 0.215 & Valid \\
\hline Pernyataan 5 & 0.702 & 0.215 & Valid \\
\hline Pernyataan 6 & 0.603 & 0.215 & Valid \\
\hline Pernyataan 7 & 0.775 & 0.215 & Valid \\
\hline Pernyataan 8 & 0.813 & 0.215 & Valid \\
\hline Pernyataan 9 & 0.702 & 0.215 & Valid \\
\hline Pernyataan 10 & 0.603 & 0.215 & Valid \\
\hline Pernyataan 11 & 0.658 & 0.215 & Valid \\
\hline
\end{tabular}

Sumber: Data Diolah (2019) 
Dari keseluruhan tabel diatas dapat diketahui bahwa nilai dari seluruh item yang ada di variabel penelitian memiliki nilai yang valid secara keseluruhan, hal ini dapat dilihat dari hasil nilai $r$ hitung yang lebih besar dengan nilai $r$ tabel.

\section{Uji Reliabilitas}

Pengukuran Reliabilitas dalam penelitian ini dilakukan dengan cara one shot (pengukuran sekali saja). Disini pengukurannya hanya dilakukan dengan pertanyaan lain atau mengukur korelasi antar jawaban pertanyaan. Alat untuk mengukur reliabilitas adalah Alpha Cronbach ( Ghozali ,2007 : 44). Suatu variabel dikatakan reliabel, apabila :

1. Hasil Alpha Cronbach $>0,60=$ reliabel

2. Hasil Alpha Cronbach $<0,60=$ tidak reliabel

Tabel 4 Hasil Uji Reliabilitas

\begin{tabular}{llll}
\hline Variabel & Batas reliabilitas & Cronbach's Alpha & Keterangan \\
\hline $\mathrm{X} 1$ & 0,60 & 0,903 & Reliabel \\
\hline $\mathrm{X} 2$ & 0,60 & 0.924 & Reliabel \\
\hline $\mathrm{Y}$ & 0,60 & 0.924 & Reliabel \\
\hline Sumber: Data Diolah $(2019)$ & &
\end{tabular}

Dari tabel 4 diatas, dapat disimpulkan bahwa reliabilitas Harga $\left(\mathrm{X}_{1}\right)$, Promosi $\left(\mathrm{X}_{2}\right)$ dan Impulse Buying (Y) dikategorikan tinggi karena nilai Cronbach's Alpha diatas dari batas reliabilitas artinya bahwa tingkat keandalan atau tingkat kepercayaan yang digunakan untuk mengukur Harga $\left(\mathrm{X}_{1}\right)$, Promosi $\left(\mathrm{X}_{2}\right)$, dan Impulse Buying (Y) telah reliabel dan dapat digunakan pada analisis lebih lanjut.

\section{Analisis Regresi Linear Berganda}

Analisis regresi linear berganda digunakan untuk melihat pengaruh semua variabel independen terhadap variabel dependen. Dalam penelitian ini, Analisis Regresi Linear Berganda digunakan untuk melihat pengaruh Harga $\left(\mathrm{X}_{1}\right)$ dan promosi $\left(\mathrm{X}_{2}\right)$ terhadap Variabel (Y), dapat dilihat pada tabel dibawah ini:

Table 5 Hasil Uji Analisis Regresi Linear Berganda

\begin{tabular}{|c|c|c|c|c|}
\hline \multirow{2}{*}{\multicolumn{2}{|c|}{ Model }} & \multicolumn{2}{|c|}{$\begin{array}{c}\text { Unstandardized } \\
\text { Coefficients }\end{array}$} & \multirow{2}{*}{$\begin{array}{c}\text { Standardized } \\
\text { Coefficients }\end{array}$} \\
\hline & & $\mathrm{B}$ & Std. Error & \\
\hline \multirow[t]{3}{*}{1} & (Constant) & 20.332 & 3.048 & \\
\hline & $\mathrm{X} 1$ & .171 & .076 & .189 \\
\hline & $\mathrm{X} 2$ & .442 & .063 & .591 \\
\hline \multicolumn{5}{|c|}{ a. Dependent Variable: Y } \\
\hline
\end{tabular}

Dari tabel diatas dapat diketahui bahwa nilai $\mathrm{c}=20.332$ dan nilai $\mathrm{b} 1=0.171$ dan $\mathrm{b} 2=0.442$ maka persamaan regresi sebagai berikut:

\section{$\mathrm{Y}=20.332+0.171 \mathrm{X}_{1}+0.442 \mathrm{X}_{2}+$ 3.048}

Berdasarkan persamaan diatas maka dapat dilihat konstanta (a) sebesar 20.332. Sedangkan pengaruh variabel $\left(\mathrm{X}_{1}\right)$ terhadap variabel $(\mathrm{Y})$ adalah positif 
terbukti dari nilai $\mathrm{b}=0.171$ yang berarti bahwa setiap kenaikan variabel $\mathrm{X}_{1}$ satu maka akan dapat menaikan variabel $\mathrm{Y}$ sebesar 0.171. pengaruh variabel $\left(\mathrm{X}_{2}\right)$ terhadap variabel (Y) adalah positif terbukti dari nilai $b=0.442$ yang berarti bahwa setiap kenaikan variabel $\mathrm{X}_{2}$ satu maka akan dapat menaikan variabel $\mathrm{Y}$ sebesar 0.442

\section{Uji Parsial (t)}

Uji $\mathrm{t}$ bertujuan untuk melihat apakah ada pengaruh yang signifikan dari variabel bebas Harga dan promosi terhadap variabel Y Cara melakukan Uji $\mathrm{t}$ dengan tingkat signifikansi $(\alpha)=$ 0,05 adalah dengan membandingkan nilai $\mathrm{t}$ hitungnya dengan $t$ tabel dan melihat nilai dari signifikannya. Apabila t hitung $>$ t tabel, maka $\mathrm{H}_{\mathrm{a}}$ diterima dan $\mathrm{H}_{\mathrm{o}}$ ditolak, dan apabila nilai signifikannya $>$ alpha $=0,05$. Sedangkan apabila $t$ hitung $<t$ tabel, maka $\mathrm{H}_{\mathrm{a}}$ ditolak dan $\mathrm{H}_{\mathrm{o}}$ diterima (Ghozali, 2011).

Table 6 Hasil Uji T

\begin{tabular}{|c|c|c|c|c|c|c|}
\hline & & \multicolumn{2}{|c|}{$\begin{array}{c}\text { Unstandardized } \\
\text { Coefficients }\end{array}$} & \multirow{2}{*}{$\begin{array}{c}\text { Standardized } \\
\text { Coefficients } \\
\text { Beta }\end{array}$} & \multirow[b]{2}{*}{$\mathrm{t}$} & \multirow[b]{2}{*}{ Sig. } \\
\hline \multicolumn{2}{|c|}{ Model } & B & Std. Error & & & \\
\hline \multirow[t]{3}{*}{1} & (Constant) & 20.332 & 3.048 & & 6.671 & .000 \\
\hline & $\mathrm{X} 1$ & .171 & .076 & .189 & 2.252 & .027 \\
\hline & $\mathrm{X} 2$ & .442 & .063 & .591 & 7.058 & .000 \\
\hline & ependent V & le: Y & & & & \\
\hline
\end{tabular}

Hasil Uji $t$ masing-masing variabel dapat disimpulkan: Hipotesis pertama dalam penelitian ini adalah terdapat pengaruh yang signifikan antara Harga $\left(\mathrm{X}_{1}\right)$ terhadap Impulse Buying (Y). berdasarkan hasil olahan data pada tabel dapat dilihat bahwa tingkat probabilitasnya sebesar $0.027<$ $\alpha=0,05$, dengan $\mathrm{t}$ hitung $>\mathrm{t}$ tabel $(2.252>1,705), \mathrm{H}_{\mathrm{o}}$ ditolak dan $\mathrm{H}_{\mathrm{a}}$ diterima, maka dapat disimpulkan bahwa terdapat pengaruh signifikan antara variable Harga $\left(\mathrm{X}_{1}\right)$ terhadap Impulse Buying (Y). Sehingga hipotesis pertama dalam penelitian ini diterima.

Hipotesis kedua dalam penelitian ini adalah terdapat pengaruh yang signifikan antara Promosi $\left(\mathrm{X}_{2}\right)$ terhadap Impulse Buying (Y). Berdasarkan hasil olahan data pada tabel 4.19 dapat dilihat bahwa tingkat probabilitasnya sebesar $0.000<\alpha=$
0,05, dengan $t$ hitung $>t$ tabel $(7.058>$ 1,705), $\mathrm{H}_{\mathrm{o}}$ ditolak dan $\mathrm{H}_{\mathrm{a}}$ diterima, maka dapat disimpulkan bahwa terdapat pengaruh signifikan antara variable Promosi $\left(\mathrm{X}_{2}\right)$ terhadap Impulse Buying (Y). Sehingga hipotesis kedua dalam penelitian ini diterima.

\section{Uji Simultan (F)}

Uji $F$ digunakan untuk mengetahui apakah secara bersamasama variabel independen berpengaruh signifikan terhadap variabel dependen. Uji $\mathrm{F}$ pada penelitian ini adalah untuk mengetahui pengaruh variabel Harga dan Promosi secara bersama-sama terhadap Impulse Buying Hasil uji ini bisa di lihat dari tabel output ANOVA. Langkah-langkah untuk melakukan uji $F$ adalah Nilai $F$ hitung akan dibandingkan dengan nilai $\mathrm{F}$ tabel. Berikut disajikan tabel hasil uji F. 
Table 7 Hasil Uji F

\begin{tabular}{|c|c|c|c|c|c|c|}
\hline Model & & Sum of Squares & Df & Mean Square & $\mathrm{F}$ & Sig. \\
\hline \multirow[t]{3}{*}{1} & Regression & 174.534 & 2 & 87.267 & 48.433 & $.000^{\mathrm{a}}$ \\
\hline & Residual & 174.776 & 97 & 1.802 & & \\
\hline & Total & 349.310 & 99 & & & \\
\hline
\end{tabular}

a. Predictors: (Constant), X2, X1

b. Dependent Variable: Y

Sumber: Data Diolah (2019)

Berdasarkan tabel diatas diperoleh hasil pengolahan data dengan menggunakan program SPSS maka diperoleh Sig $0,000<0,05$ dengan $\mathrm{F}$ hitung $48.433>\mathrm{F}$ tabel 2,70. Ini berarti variabel Harga $\left(\mathrm{X}_{1}\right)$ dan variabel Promosi $\left(\mathrm{X}_{2}\right)$ secara bersama-sama mempengaruhi Impulse Buying (Y).

\section{Koefisien Determinasi $\left(\mathbf{R}^{\mathbf{2}}\right)$}

Koefisien determinasi $\left(\mathrm{R}^{2}\right)$ pada intinya mengukur seberapa jauh kemampuan model dalam menerangkan variasi variabel dependent. Nilai Koefisien Determinasi (R2) adalah antara 0 dan 1 . Bila nilai $\mathbf{R}^{2}$ mendekati 0 berarti kemampuan variabel Independent dalam menjelaskan variasi variabel dependen amat terbatas. Jika nilai $\mathrm{R}^{2}$ bergerak mendekati 1 berarti variabel independen memberikan hampir semua informasi yang dibutuhkan untuk memprediksi variasi variabel dependen. Hasil uji model penelitian $\left(\mathrm{R}^{2}\right)$ dapat dilihat pada tabel dibawah ini.

Table 8 Koefisien Determinasi $\left(\mathbf{R}^{2}\right)$

\begin{tabular}{lcrrr}
\hline Model & $\mathrm{R}$ & R Square & $\begin{array}{c}\text { Adjusted R } \\
\text { Square }\end{array}$ & $\begin{array}{c}\text { Std. Error of the } \\
\text { Estimate }\end{array}$ \\
\hline $1 \quad .707^{\mathrm{a}}$ & .500 & & .489 & 1.342 \\
\hline a. Predictors: (Constant), X2, X1 & & & \\
\hline b. Dependent Variable: Y & & & \\
\hline Sumber: Data Diolah (2019) &
\end{tabular}

Dari hasil perhitungan menggunakan program SPSS pada tabel diatas dapat diketahui bahwa dilihat nilai $\mathrm{R}$ Square $=0.500$ artinya 50 persen. variabel $\mathrm{Y}$ di jelaskan oleh Variabel Harga $\left(\mathrm{X}_{1}\right)$ dan Promosi $\left(\mathrm{X}_{2}\right)$. Sementara itu sisanya yaitu sebesar 50 persen dijelaskan oleh variabel lain yang tidak dijelaskan dalam penelitian ini.

\section{Tinjauan Ekonomi Islam Mengenai Pengaruh Harga dan Promosi Terhadap Impulse Buying}

Dalam konsep ekonomi Islam harga ditentukan oleh keseimbangan permintaan dan penawaran. Keseimbangan ini tidak terjadi bila antara penjual dan pembeli tidak bersikap saling merelakan. Kerelaan ini ditentukan oleh penjual dan pembeli dalam mempertahankan kepentingannya atas barang tersebut.

Dalam ekonomi Islam siapa pun boleh berbisnis. Namun demikian, dia tidak boleh melakukan ikhtikar, yaitu mengambil keuntungan di atas keuntungan normal dengan menjual lebih sedikit barang untuk harga yang 
lebih tinggi (Sholihah, 2017). Setiap keputusan ekonomi seorang manusia tidak terlepas dari nilai-nilai moral dan agama karena setiap kegiatan senantiasa dihubungkan kepada syariat. Al-Qur'an menyebut ekonomi dengan istilah iqtishad (penghematan, ekonomi), yang secara literal berarti 'pertengahan' atau 'moderat'. Seorang muslim diminta untuk mengambil sebuah sikap moderat dalam memperoleh dan menggunakan sumber daya. Dia tidak boleh israf (berlebih-lebihan), tetapi juga dilarang pelit (bukh).

Penelitian terkait faktor harga diperoleh bahwa harga memiliki pengaruh signifikan terhadap impulse buying, hal tersebut sejalan dengan penelitian yang dilakukan oleh Dalihade (2017) dan Wahyudi (2017) menunjukkan bahwa harga merupakan faktor yang berpengaruh signifikan terhadap impulse buying.

Begitu juga dalam hal melakukan promosi. Promosi dalam Islam adalah mempromosikan barang dagangan dengan cara yang paling tepat sehingga menarik minat calon pembeli. Promosi berdasarkan prinsip syariah adalah promosi yang jujur, transparan, dan menjelaskan apa adanya. Di dalamnya tidak terdapat unsur-unsur kebohongan dan penipuan baik dari segi kuantitas maupun kualitas. Pada satu sisi harus menyampaikan apa adanya walaupun mungkin tidak akan berdampak luar biasa bagi penjualan karena tidak dibesar-besarkan, namun berkah. Tapi pada sisi lain tidak dibenarkan menyampaikan informasi yang mengandung kebohongan, apalagi penipuan (Sunjoto, 2017).

Penelitian ini sejalan dengan penelitian yang dilakukan oleh Fadliyah (2015), Putri (2017) dan Alfaiz (2018) dimana promosi merupakan faktor yang berpengaruh signifikan terhadap impulse buying. Promosi dalam perspektif islam juga dapat diambil contoh dari sistem promosi yang dilakukan oleh Rasulullah SAW. Promosi yang dilakukan Rasulullah SAW lebih menekankan pada hubungan dengan pelanggan. Adapun strategi yang dilakukan Rasulullah dalam mempromosikan produknya adalah sebagai berikut (Lestari, 2016) :

1. Rasulullah senantiasa memulai promosi dari dirinya sendiri, yaitu berpenampilan menawan, bersih dan rapi.

2. Nabi Muhammad SAW menyatakan bahwa membangun sillaturahmi atau membangun relasi merupakan kunci keberhasilan dalam pemasaran.

3. Nabi Muhammad SAW lebih mengutamakan keberkahan daripada keberhasilan penjualan.

4. Nabi Muhammad SAW sangat memahami pelanggannya.

5. Memberikan pelayanan yang hebat.

6. Menjalin hubungan komunikasi dengan baik agar tidak terjadi perselisihan antara orang yang melaksanakan jual beli.

7. Menciptakan keterlibatan dan menawarkan pilihan, artinya tidak ada paksaan dalam menentukan pilihan bagi pembeli

Selain aspek di atas, ada etika-etika yang harus diperhatikan dalam berpromosi sesuai dengan petunjuk Rasulullah, yaitu sebagai berikut:

1. Prinsip esensial dalam bisnis adalah kejujuran.Menurut Nabi, kejujuran akan membawa kepada kebajikan dan kebajikan akan membawa pada surga. Rasulullah melarang segala bentuk aktivitas bisnis yang dilakukan dengan penipuan karena penipuan dapat merugikan orang lain dan melanggar hak asasi dalam bisnis yaitu suka sama suka.

2. Amanah dan profesioanl dalam bisnis.Bersikap dan berperilaku amanah sangatlah dianjurkan dalam 
Islam dan orang yang tidak amanah disebut pengkhianat, termasuk salah satu ciri orang munafik.

3. Kesadaran tentang signifikansi sosial dalam kegiatan bisnis.Pelaku bisnis menurut Islam tidak hanya sekedar mengejar keuntungan sebanyak-banyaknya sebagaimana yang diajarkan dalam ekonomi kapitalis, tetapi juga berorientasi kepada sikap ta'awun (tolongmenolong) sebagai implikasi sosial kegiatan bisnis.

4. Tidak melakukan sumpah palsu. Nabi Muhammad melarang sesorang melakukan sumpah palsu dalam segala hal, termasuk dalam bisnis. Orang yang melakukan sumpah palsu pada dasarnya telah berbuat dosa besar sebagaimana halnya dosa besar sebagaimana halnya dosa-dosa besar yang lain seperti menyekutukan Allah, durhaka kepada orang tua, berina, membunuh, dan sebagainya.

5. Tidak berpura-pura menawarkan harga tinggi, agar orang lain tertarik membeli dengan harga tersebut. Cara bisnis ini dikenal dengan jual beli najasy, yaitu menawar harga tinggi untuk menipu pengunjung atau calon pembeli lainnya.

6. Bersikap ramah tamah dalam melakukan aktivitas bisnis.

7. Tidak menjelek-jelekkan bisnis orang lain agar orang membeli kepadanya.

8. Tidak melakukan penimbunan (ihtikar). Ihtikar yaitu menumpuk dan menyimpan barang dalam masa tertentu dengan tujuan agar harganya suatu saat menjadi naik dan keuntungan besarpun diperoleh.

9. Melakukan takaran, ukuran, dan timbangan secara benar dan tidak menguranginya.
10. Membayar upah kepada pekerja atau karyawan segera munguranginya

Dalam Islam, konsumsi tidak dapat dipisahkan dari peranan keimanan. Peranan keimanan menjadi tolak ukur penting karena keimanan memberikan cara pandang dunia yang cenderung mempengaruhi kepribadian manusia. Keimanan sangat mempengaruhi kuantitas dan kualitas konsumsi baik dalam bentuk kepuasan material maupun spiritual. Dari sinilah kemudian terbentuk perilaku konsumen muslim, yaitu:

1. Dalam mengkonsumsi, kepuasan konsumen bukan fungsi satu-satunya atas barang konsumsi dan komoditas, tetapi juga fungsi dari ridha Allah.

2. Seorang muslim dilarang untuk mengkonsumsi hal-hal yang dilarang oleh Syariat.

3. Seorang muslim dilarang untuk membayar atau menerima bunga dari pinjaman dalam bentuk apapun. Suku bunga tersebut dapat digantikan oleh biaya dalam kaitannya dengan profit sharing.

4. Anggaran yang digunakan adalah pendapatan bersih setelah pembayaran zakat.

5. Konsumen harus menahan diri dari konsumsi yang berlebihan yang berarti konsumen muslim tidak harus menghabiskan seluruh pendapatan bersihnya untuk konsumsi barang dan jasa.

Lebih lanjut, Yusuf Qardhawi juga menambahkan bahwa konsumsi harus memerhatikan tingkat maslahah, yaitu pada diri sendiri, keluarga dan kepentingan maslahah orang banyak bahkan harus akhirat oriented. Ajaran Islam mengajarkan untuk hidup sederhana, dan menjauhi sikap boros (memubadzirkan harta) dan bermewahmewahan. 


\section{PENUTUP}

Kesimpulan

Hasil penilitian ini menunjukkan bahwa variable Harga dan Promosi mempunyai pengaruh yang signifikan terhadap Impulse Buying baik secara Partial maupun secara Simultan dengan nilai signifikansi X1 (Harga) sebesar 0.027, nilai signifikansi X2 (Promosi) sebesar 0.000 dan nilai signifikansi Ftest sebesar 0.000. Serta Nilai koefisien Determinasi $\left(\mathrm{R}^{2}\right)$ sebesar 0.500 ini berarti 50\% Impulse Buying di pengaruh Harga dan Promosi dan 50\% dipengaruhi oleh variabel lain yang tidak diteliti dalam penelitian ini.

\section{Saran}

Dari hasil penelitian yang telah dilakukan peneliti, maka dapat dikatakan mahasiswa Jurusan Ekonomi Syariah Fakultas Agama Islam Universitas Islam Riau termasuk dalam kelompok masyarakat yang menerapkan Ekonomi Syariah dalam pengaruh perilaku konsumen terhadap keputusan pembelian telepon genggam. Artinya mereka menerapkan konsep yang sesuai dengan ajaran agama Islam dalam melakukan pembelian telepon genggam. Tidak melampaui batas kewajaran, dan secara positif. Karena Al-Qur'an melarang membelanjakan harta secara berlebih-lebihan semata-mata menuruti hawa nafsu,sementara disisi lain juga mengutuk perbuatan menjauhkan diri darikesenangan menikmati benda-benda yang baik dan halal dalam kehidupan.

\section{DAFTAR PUSTAKA}

Alfaiz, M. D. (2018). Faktor Yang Mempengaruhi Impulsive Buying Konsumen Pands Yogyakarta Dalam Perspektif Perilaku Konsumsi Islami.

Aprillia, R. (2017). Fluktuasi Harga Dan Sistem Pengambilan Keuntungan Dalam Jual Beli
Tiket Pesawat Perspektif Hukum Islam (Studi Pada Seven Light Tour And Travel Kecamatan Sukarame, Bandar

Lampung) (Doctoral dissertation, UIN Raden Intan Lampung).

Dalihade, M. P., Massie, J. D., \& Tielung, M. V. (2017). Pengaruh Potongan Harga dan Store Atmosphere Terhadap Impulse Buying Pada Matahari Departement Store Mega Mall Manado. Jurnal EMBA: Jurnal Riset Ekonomi, Manajemen, Bisnis dan Akuntansi, 5(3).

Fadliyah, L. (2015). Faktor-faktor yang mempengaruhi impulse buying pada konsumen jilbab di Pasar Johar Semarang (Doctoral dissertation, UIN Walisongo).

Hamzah, M. L., Rusilawati, E., \& Purwati, A. A. (2018). Sistem Aplikasi Sarana Prasarana Perguruan Tinggi Menggunakan Teknologi Near Field Communication Berbasis Android. INTECOMS: Journal of Information Technology and Computer Science, 1(2), 251261.

Lestari, S. P. (2016). Hubungan Komunikasi Pemasaran dan Promosi dengan Keputusan Memilih Jasa Layanan Kesehatan (Studi pada Rumah Sakit Islam Lumajang). Majalah Ilmiah Inspiratif, 2(2).

Miranda, Y. C. (2016). Kajian Terhadap FaktorYang Mempengaruhi Impulse BuyingDalam Online Shopping. Competence: Journal of Management Studies, 10(1).

Purwati, A. A., Malau, R. F., \& Hamzah, M. L. (2017). Strategi Pemasaran Jasa Dan Kepuasan Pelanggan Indihome Pt Telkom 
Indonesia. Procuratio: Jurnal Ilmiah Manajemen, 8(1), 74-93.

Pertaminawati, H. (2016). Analisis pemikiran Ibnu Khaldun tentang mekanisme pasar dan penetapan harga dalam perekonomian Islam. Kordinat Jurnal Komunikasi Antar Perguruan Tinggi Agama Islam, 15(2), 195216.

Putri, R. A. (2017). Pengaruh desain kemasan produk makanan ringan "Mini Oreo" terhadap impulsive buying: Studi kasus pada konsumen Hypermart Malang Town Square (Doctoral dissertation, Universitas Islam Negeri Maulana Malik Ibrahim).

Rahmasari, L. (2016). Menciptakan Impulse Buying. Majalah ilmiah informatika, 1(3).
Sholihah, U. M., Rachma, N., \& Slamet, A. R. (2017). Pengaruh Shopping Life Style, Fashion Involvement, Hedonic Shopping Motivation Dan Sales Promotion Terhadap Impulse Buying Di Malang Town Square, Dan Mall Olympic Garden (Study Pada Mahasiswa Fakultas Ekonomi Universitas Islam Malang). Jurnal Ilmiah Riset Manajemen, 6(1).

Sunjoto, A. R. (2017). Strategi Pemasaran Swalayan Pamella dalam Perspektif Islam (Studi Kasus Swalayan Pamella Yogyakarta Tahun 2010). JESI (Jurnal Ekonomi Syariah Indonesia), 1(2), 45-64.

Wahyudi, S. (2017). Pengaruh Price Discount terhadap Impulse Buying. VALUTA, 3(2), 276289. 